Article

\title{
Zero Tillage Systems Conserve Arbuscular Mycorrhizal Fungi, Enhancing Soil Glomalin and Water Stable Aggregates with Implications for Soil Stability
}

\author{
Thomas I. Wilkes ${ }^{1, *(\mathbb{D})}$, Douglas J. Warner ${ }^{2} \mathbb{D}$, Veronica Edmonds-Brown ${ }^{1}$, Keith G. Davies ${ }^{1}$ and Ian $^{\text {Denholm }}{ }^{1}$ \\ 1 Department of Psychology, Sport and Geography, School of Life and Medical Sciences, College Lane Campus, \\ University of Hertfordshire, Hatfield, Hertfordshire AL10 9AB, UK; v.r.edmonds-brown@herts.ac.uk (V.E.-B.); \\ k.davies@herts.ac.uk (K.G.D.); i.denholm@herts.ac.uk (I.D.) \\ 2 Agriculture and Environment Research Unit, School of Life and Medical Sciences, College Lane Campus, \\ University of Hertfordshire, Hatfield, Hertfordshire AL10 9AB, UK; d.j.warner@herts.ac.uk \\ * Correspondence: t.wilkes@herts.ac.uk
}

check for updates

Citation: Wilkes, T.I.; Warner, D.J.; Edmonds-Brown, V.; Davies, K.G.; Denholm, I. Zero Tillage Systems Conserve Arbuscular Mycorrhizal Fungi, Enhancing Soil Glomalin and Water Stable Aggregates with Implications for Soil Stability. Soil Syst. 2021, 5, 4. https://doi.org/ 10.3390 / soilsystems 5010004

Received: 24 December 2020 Accepted: 11 January 2021 Published: 13 January 2021

Publisher's Note: MDPI stays neutral with regard to jurisdictional clai$\mathrm{ms}$ in published maps and institutional affiliations.

Copyright: (C) 2021 by the authors. Licensee MDPI, Basel, Switzerland. This article is an open access article distributed under the terms and conditions of the Creative Commons Attribution (CC BY) license (https:// creativecommons.org/licenses/by/ $4.0 /)$.

\begin{abstract}
Arbuscular Mycorrhizal (AM) fungi form mutualistic symbiotic relationships with approximately $80 \%$ of terrestrial plant species, while producing the glycoprotein glomalin as a structural support molecule along their mycelial network. Glomalin confers two benefits for soils: (1) acting as a carbon and nitrogen storage molecule; (2) the binding of soil microaggregates $(<250 \mu \mathrm{m})$ to form larger, more stable structures. The present study aimed to test the hypothesis that a correlation between glomalin and soil aggregation exists and that this is influenced by the method of seedbed preparation. The soils from two crops of winter wheat in Hertfordshire, UK, practising either conventional (20 cm soil inversion) or zero tillage exclusively, were sampled in a $50 \mathrm{~m}$ grid arrangement over a 12 month period. Glomalin and water stable aggregates (WSA) were quantified for each soil sample and found to be significantly greater in zero tillage soils compared to those of conventional tillage. A stronger correlation between WSA and glomalin was observed in zero tillage (Pearson's coeffect 0.85 ) throughout the cropping year compared to conventional tillage (Pearson's coeffect 0.07). The present study was able to conclude that zero tillage systems are beneficial for AM fungi, the enhancement of soil glomalin and soil erosion mitigation.
\end{abstract}

Keywords: tillage; glomalin; zero till; conventional till; water stable aggregates

\section{Introduction}

Arbuscular Mycorrhizal (AM) fungi form mutualistic symbiotic relationships with approximately $80 \%$ of terrestrial plant species and provide immobile soil nutrients typically not available to the plant [1]. Through the plant-fungi relationship, AM fungi can improve plant growth promoting hormones, as well as contributing to environmental factors such as soil aggregate stability and soil carbon stores [2].

AM fungi produce the glycoprotein glomalin as a structural support molecule along their mycelial network [3]. Additionally, glomalin acts as a long-term carbon and nitrogen storage molecule, containing an estimated $20-30 \%$ carbon and $3-5 \%$ nitrogen, whilst remaining in soils for up to 40 years [4]. Through the established plant-fungal symbiosis relationship, AM fungi and glomalin can play a crucial role in the sequestration of carbon dioxide from the atmosphere with photosynthetic carbohydrates being provided by the host plant via the intracellular fungal exchange organ, arbuscules [4-7]. Such photosynthetic carbons, provided to AM fungi, account for $20 \%$ of the total photosynthate [8]. The promotion of AM fungi growth increases carbon dioxide $\left(\mathrm{CO}_{2}\right)$ intake and photosynthesis, which then enhances fungal biomass and glomalin [6]. Glomalin has the potential to bind soil aggregates and has been described as an adhesive glue-like compound in [4]. The growth of AM fungal mycelia further aids in the binding of soil aggregates [5]. However, 
when quantifying glomalin, glomalin related soil proteins (GRSP) are reported due to the undefined structure of glomalin [6].

Soil inversion, a component of land preparation practices in conventional tillage (CT) agricultural systems, has been widely applied globally for several decades [9]. More recently, conservational agriculture systems such as zero tillage (ZT) have been implemented more widely [10]. Within the UK, CT has been reported to disturb soils to a depth of $20 \mathrm{~cm}$; however, CT can have a maximum soil inversion of $30 \mathrm{~cm}$ [11]. This is in stark contrast to the nominal soil disturbance due to the employment of ZT. Not only does ZT reduce soil disturbance, but also reductions in workload, fuel consumption and soil erosion are also reported [10].

The carbon stored in soils can vary in response to land management practice. Conventional tillage inverts soil to a greater depth, resulting in the greatest disturbance and soil aeration. Soil aeration increases the rate of mineralisation of soil organic matter (SOM) and the associated release of soil carbon as $\mathrm{CO}_{2}$ into the atmosphere [12,13]. This reduces the soil organic carbon (SOC) equilibrium of the soil and its capacity for carbon storage. Carbon compounds previously protected from microbial metabolism due to adsorption on mineral surfaces and the occlusion within soil aggregates and particulates now become available to degradation through metabolic pathways that were formerly unable to proceed [14]. As the highest quantities of SOC are stored within the top $30 \mathrm{~cm}$ of a soil profile [15], which is also the maximum depth of soil disturbance from a CT mouldboard plough. This carbon is therefore at risk of being lost to the atmosphere due to soil inversion. Not only is SOC lost in response to $\mathrm{CT}$, but soil biodiversity, including the delicate soil microbiome, is altered [16-19]. Further, CT physically breaks apart fungal mycelia, damaging hyphal structures that maintain soil glomalin concentrations, resulting in reduced glomalin production in CT soils and, thereby, reducing the aggregate stability of soils and leading to increases in soil erosion $[9,10,14,16]$. In a directly sown ZT system, soils are not disturbed to the same degree, allowing fungal mycelia and the adhesive quality of glomalin to remain intact. Maintenance of the glomalin-WSA (water stable macroaggregates) relationship, indicative of an intact AM fungal hyphae network that both produces glomalin and physically binds soil particles, is critical to soil function $[3,20]$.

Previous reports describe the existence of a positive correlation between soil aggregates and glomalin concentrations $[6,21,22]$. However, these studies do not address the influences of tillage as a land management strategy towards AM fungi and soil aggregates. This study aims to investigate and test the hypothesis that two land management practices, CT and ZT, (1) influence AM fungi and (2) indirectly affect water stable macroaggregates (WSA), soil glomalin and SOM. The importance of considering WSA and soil glomalin in combination in the context of the soil microbiome are discussed.

\section{Materials and Methods}

\subsection{Sampling Sites}

Samples were taken from several sites across 2 farms in Hertfordshire, UK. Farm A practised CT exclusively (soil inversion to $20 \mathrm{~cm}$ via mouldboard plough), while Farm B practised ZT exclusively for a period of 8 years. Farm records provided by participating land managers included details of soil type, crop history, agrochemical application, fertiliser type and application rates. This was then used to identify fields on each farm with similar crop histories (cereal crops), dimensions and soil types (sandy loam) for comparison purposes and to inform sampling regimes. A $50 \mathrm{~m}$ sampling grid was constructed from farm and boundary maps provided by the respective farm managers for selected fields with known crop histories of cereal crops with current winter wheat rotation. Samples were taken in both the CT and ZT ( $n=260$ and 216, respectively, for each sampling period, comprised of a soil core taken to a maximum depth of $40 \mathrm{~cm}$ and subdivided into $4 \times 10 \mathrm{~cm}$ subsamples for each tillage type) treatments: 5 months post cultivation of the CT treatment (February 2019) and pre-harvest (May 2019). Each sample was taken to a maximum depth of $40 \mathrm{~cm}$, using a single core, and divided into $10 \mathrm{~cm}$ sub-sections for gradient depth analysis. 


\subsection{Soil Physical Properties}

Soil texture was determined using the methodology described by Brown and Wherrett [23]. Soil aggregates were quantified with Equation (1). Field-sampled soils (100 g) were passed through a $2 \mathrm{~mm}$ sieve to remove large rock and stone materials and then a $0.2 \mathrm{~mm}$ sieve under a constant flow of water for $60 \mathrm{~s}$.

Water Stable Aggregates $(\%)=\frac{\text { Mass of soil remaining on sieve }(g)}{\text { Total mass of soil originally placed on sieve }(g)} \times 100$

Soil organic matter was determined based on the approach of Myrbo et al. [24].

\subsection{Glomalin-Related Soil Protein Extraction}

Glomalin-related soil protein (GRSP) was extracted via a modified methodology from Wright and Upadhyaya [20] to measure soil glomalin. Briefly, $1 \mathrm{~g}$ of soil was suspended in $8 \mathrm{~mL} 50 \mathrm{mM}$ trisodium citrate dihydrate (Thermo Fisher Scientific ${ }^{\circledR}$, Loughborough, Leicestershire, UK) and kept at autoclave conditions $\left(121^{\circ} \mathrm{C} 15 \mathrm{psi}\right)$ for $60 \mathrm{~min}$. Soils were then centrifuged at $1000 \times g$ for 2 min to remove suspended soil particles. Supernatant was further centrifuged at $6800 \times g$ for $10 \mathrm{~min}$, a total of three times to remove impurities within the sample. Of the centrifuged sample, $1 \mathrm{~mL}$ was used for the Bradford protein assay (Coomassie Protein Assay Reagent, Thermo Fisher Scientific ${ }^{\circledR}$, Loughborough, Leicestershire, UK) at a photospectrometer (Cecil ${ }^{\circledR}$ 1021, Cambridge, UK) absorbance of $595 \mathrm{~nm}$. Glomalin was able to be precipitated through minimal (dropwise) additions of 1 mol hydrochloric acid (Fisher Scientific ${ }^{\circledR}$, Loughborough, Leicestershire, UK) followed by drying at $60^{\circ} \mathrm{C}$ until dry and weighing.

\subsection{Software and Statistics}

$\mathrm{R}$ (version 3.5.3, Hamilton, ON, Canada) was used for the ANOVA, $T$ test, Pearson's correlations and $\mathrm{R}^{2}$ values.

\section{Results}

A strong correlation was observed between WSA and GRSP content in the soil of the ZT treatment for both the 5 month period post seedbed preparation (Figure 1a: Pearson's coefficient $=0.85: r^{2}=0.73$ ) and pre-harvest (Figure 1b: Pearson's coefficient $=0.87$ : $\mathrm{r}^{2}=0.76$ ). A negligible correlation was evident in the CT treatment in either sampling period (Pearson's coefficient $=0.07$ and 0.13 , respectively). A statistically significant difference exists between WSA and total glomalin for CT- and ZT-treated soils during sampling periods 5 months post seedbed preparation (WSA, $p<0.0001$, df: 477 , t stat: -3.66 , paired unequal variance $T$ test: glomalin, $p<0.00001$, df: 321 , $\mathrm{t}$ stat: -10.45 , paired uneven $T$ test) and pre harvest (WSA, $p<0.0001$, df: 345, $\mathrm{t}$ stat: -10.53 , paired uneven $T$ test: glomalin, $p<0.00001$, df: 321 , t stat: -10.45 , paired unequal variance $T$ test). The total glomalin measured on ZT soils relative to CT was additionally greater $(p=0.05)$, a mean of $56.01 \mathrm{~g} / 0.1 \mathrm{~m}^{3}$ and $42.94 \mathrm{~g} / 0.1 \mathrm{~m}^{3}$, respectively. The comparisons of the ZT and $\mathrm{CT}$ treatments refer to sampling points for sandy loam soil only. The four soil textures present in the ZT treatment were analysed further as potential variables. Figure 2 reveals that a strong positive correlation exists between WSA and total glomalin irrespective of soil texture within the ZT field (Pearson's coefficient $=0.75$ to 0.87 ). Soil texture was found to have a significant impact on the quantity of total glomalin $(p<0.00001, \mathrm{df}: 3,212$, F value: 16.75, F critical: 2.65, Single factor ANOVA) and overall WSA ( $p<0.00001$, df: 3, 212, F value: 18.85, F critical: 2.65 , Single factor ANOVA). 

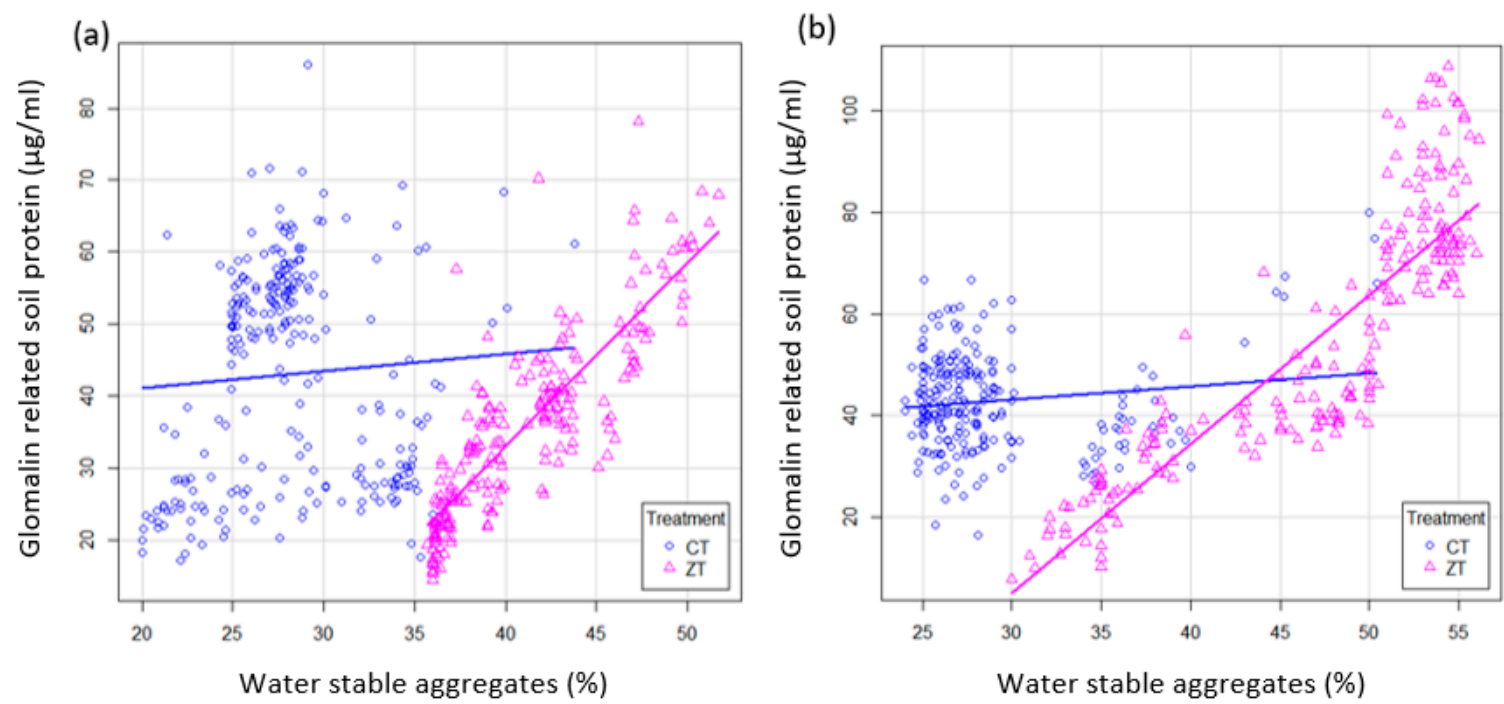

Figure 1. Correlation between water-stable aggregates (WSA) and glomalin-related soil protein (GRSP) for (a) the 5 month period post seedbed preparation and (b) pre harvest. Pearson's correlation (a) $0.85\left(\mathrm{r}^{2}, 0.73\right)$ for zero tillage (ZT) and 0.07 $\left(\mathrm{r}^{2}, 0.004\right)$ for conventional tillage (CT): (b) $0.87\left(\mathrm{r}^{2}, 0.76\right)$ in ZT and $0.13\left(\mathrm{r}^{2}, 0.02\right)$ for CT. Data points are indicative of all sampled soils from their respective sites. Mean GRSP 5 months post cultivation was measured at $43.03 \mathrm{~g} / 0.1 \mathrm{~m}^{3}(\mathrm{n}=261)$ and $36.0 \mathrm{~g} / 0.1 \mathrm{~m}^{3}(\mathrm{n}=217)$ for CT and ZT, respectively. Pre harvest total glomalin produced means of $43.0 \mathrm{~g} / 0.1 \mathrm{~m}{ }^{3}$ $(\mathrm{n}=261)$ and $56.0 \mathrm{~g} / 0.1 \mathrm{~m}^{3}(\mathrm{n}=217)$ for CT and ZT respectively. Mean WSA 5 months post cultivation was measured at $28.1 \%(n=261)$ and $41.2 \%(n=217)$ for CT and ZT respectively. Pre harvest total WSA produced means of $29.7 \%(n=261)$ and $47.3 \%(n=217)$ for CT and $Z T$, respectively.

(a)

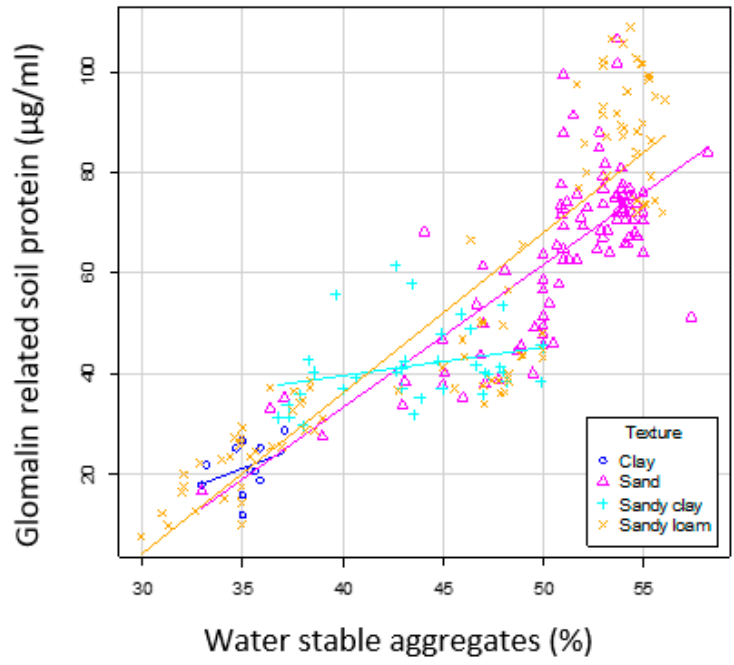

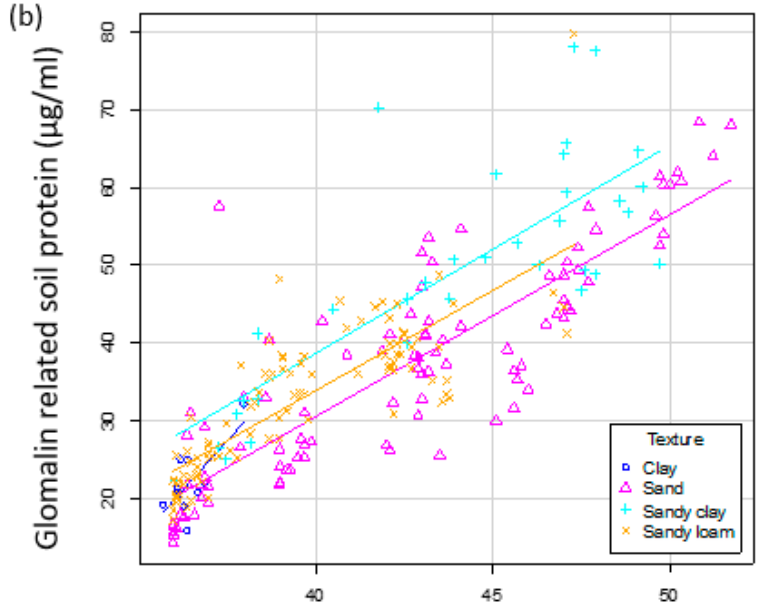

Water stable aggregates (\%)

Figure 2. Correlations between water-stable aggregates (WSA) and glomalin-related soil protein (GRSP) for (a) the 5 month period post seedbed preparation and (b) pre harvest between soil textures within the zero tillage (ZT)-treated field 5 months post seedbed preparation. Conventional tillage treated soils were homogenous for sandy loam soils only and were unable to produce soil texture comparatives to the extent of ZT soils. Pearson correlations measured in (a) clay textures at a value of $0.75\left(\mathrm{r}^{2}-0.56\right)$, sand $0.87\left(\mathrm{r}^{2}-0.76\right)$, sandy clay $0.81\left(\mathrm{r}^{2}-0.65\right)$ and sandy loam soils at $0.83\left(\mathrm{r}^{2}-0.68\right)$. Pearson correlations in (b) measured clay $0.12\left(r^{2}-0.01\right)$, sand $0.75\left(r^{2}-0.56\right)$, sandy loam $0.90\left(r^{2}-0.81\right)$ and sandy clay $0.36\left(r^{2}-0.13\right)$.

Soil depth was observed to have implications on organic matter for CT $(p<0.00001$, df: 3, 256, F value: 51.90, F critical: 2.64, Single factor ANOVA) and ZT ( $p<0.00001$, df: 3 , 212, F value: 25.94, F critical: 2.65, Single factor ANOVA) (Figure 3). Top soils $(<10 \mathrm{~cm}$ ) measured as significantly different $(p<0.00001$, df: 110, t.stat: 8.27 , unequal variance $T$ test) between tillage practices, with further significance in soils sampled from $40 \mathrm{~cm}$ soil depths ( $p<0.00001$, df: 102, t.stat: 6.67, unequal variance $T$ test). Both of these depths were 
observed to have the greatest significant difference $\left(^{*}\right)$ in organic matter between tillage treatments. Soils at a depth of $30 \mathrm{~cm}$ were also measured to contain different degrees of organic matter between tillage practices $(p<0.03$, df: 106 , t.stat: 1.88 , unequal variance $T$ test). Differences in mean organic matter at soil depths of $20 \mathrm{~cm}$ were not significant between tillage methods ( $p=0.28$, df: 114 , t.stat: 0.58 , unequal variance $T$ test).

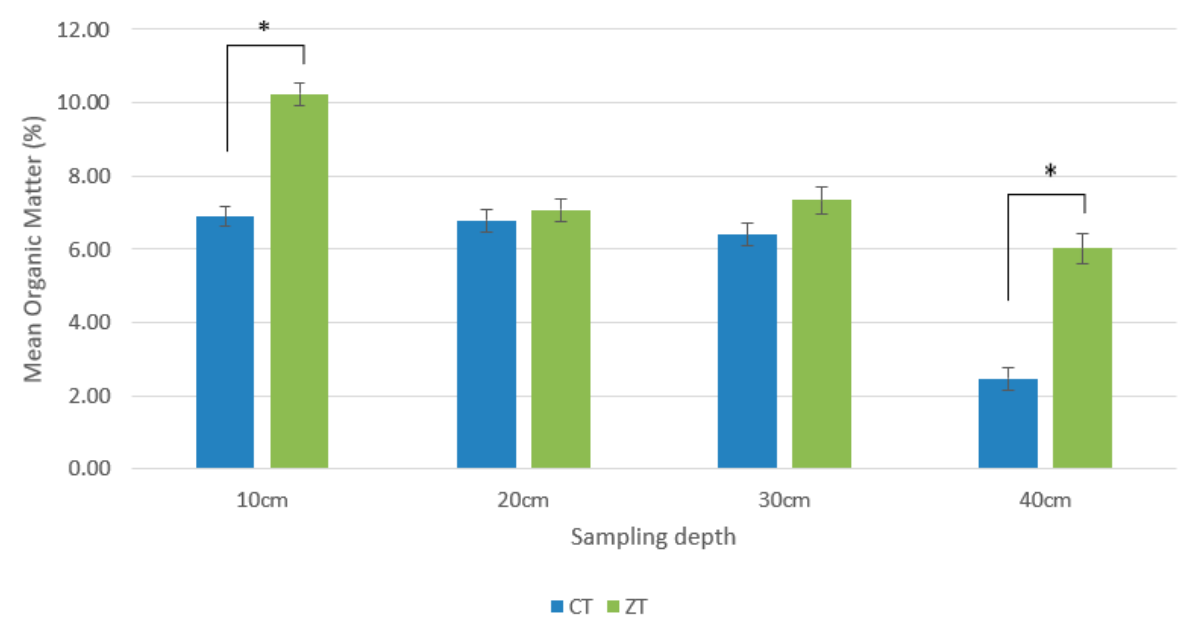

Figure 3. Mean $(n=65$ per depth—conventional tillage $(C T): n=53$ per depth—zero tillage $(Z T))$ percentage organic matter for $\mathrm{CT}$ and ZT samples soils from a period 5 months post seedbed preparation, no statistical differences were observed for pre harvest samples (data not shown). Greatest significance was observed between tillage treatments at $10 \mathrm{~cm}$ and $40 \mathrm{~cm}$ sampling depth $\left(^{*}\right)$ $(p<0.00001)$. Error bars constructed from SEM.

Conventional tillage soils produced an increase in quantifiable GRSP post cultivation in the zone of tillage $(<20 \mathrm{~cm})$, corresponding to crop growth stage GS21 [25] and the increased presence of host plant roots (February-May 2019), supporting the glomalin producing AM fungi.

ZT mean GRSP (Figure 4) followed a similar increase at all sampling depths with the greatest soil glomalin concentration measured in May 2019 (pre harvest). Statistical testing between tillage treatments produced $T$ test significance for each sampling depth between sampling periods of each tillage treatment $(p<0.0001, \mathrm{df}: 83$, t.stat: 7.15, paired unequal variance $T$ test), with the exception of $40 \mathrm{~cm}$ depth samples from pre harvest (May 2019), which showed no significance between tillage treatments ( $p=0.26$, df: 71 , t.stat: -1.13 , paired unequal variance $T$ test).

WSA of CT soils (Figure 5) was observed to decrease after the initial receipt of tillage in September 2018 ( $p<0.00001$, df: 3, 256, F value: 231.27, F critical: 2.64, Single factor ANOVA) (data not shown) to the greatest reduction in WSA between February and March 2019. WSA for soils sampled at $40 \mathrm{~cm}$ were recorded to sharply increase aggregation. 
(a)

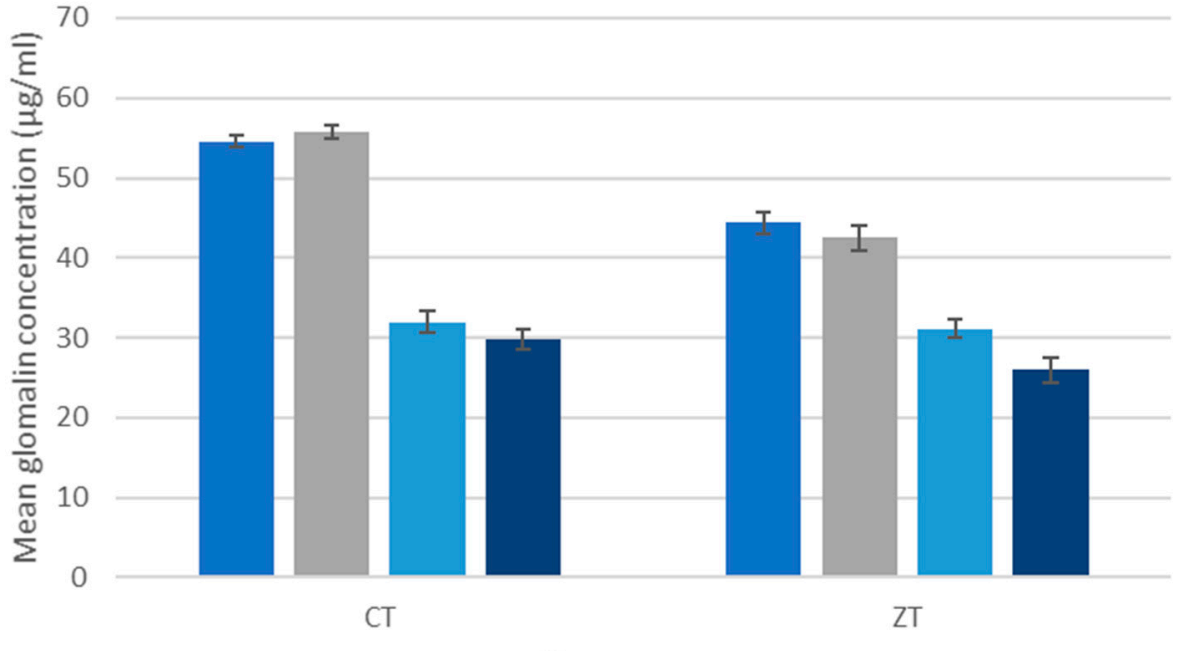

Tillage treatment

(b)

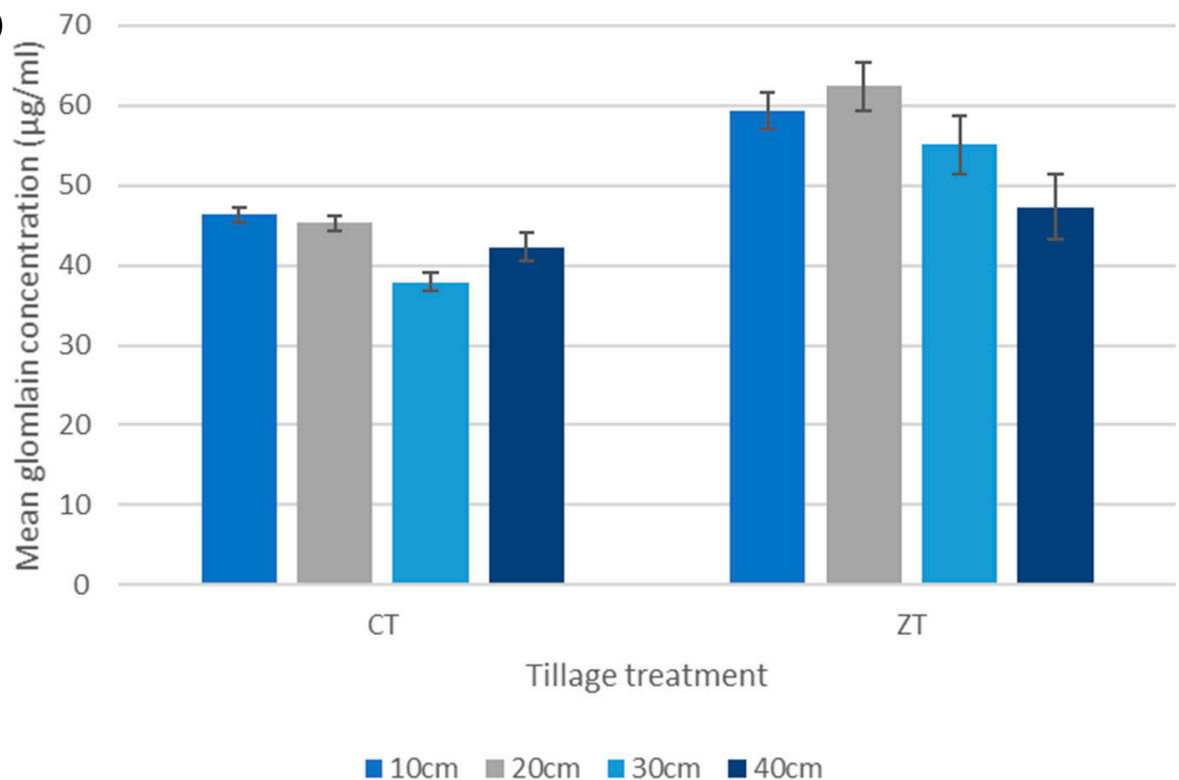

Figure 4. Mean glomalin concentration $(\mu \mathrm{g} / \mathrm{mL})$ between tillage treatment (conventional tillage $(\mathrm{CT})$ and zero tillage (ZT)) in (a) February and (b) May 2019. Soils were sampled to a maximum depth of $40 \mathrm{~cm}$ at $10 \mathrm{~cm}$ increments. Extractions of glomalin related soil protein (GRSP) were performed until the Bradford assay was unable to quantify any further GRSP. Zone of tillage in CT treatments was noted to be to a sampling depth of $20 \mathrm{~cm}$ soil inversion. Error bars constructed from SEM.

Initial WSA of ZT soils (Figure 5) were equally distributed throughout the soil depths. Increases in aggregation were recorded for 20 and $30 \mathrm{~cm}$ depth soil samples, with a maximum increase in May 2019 before all sampling depths reduced marginally towards the end of the sampling year (August 2019, data not shown). The WSA of soils at all sampling depths in ZT management were higher than those of CT managed soils $(p<0.0001$, df: 68 , t.stat: -48.06 , paired unequal variance $T$ test), with the exception of the $40 \mathrm{~cm}$ depth samples from August 2019 ( $p=0.39$, df: 112, t.stat: 0.87, paired unequal variance $T$ test). 
(a)

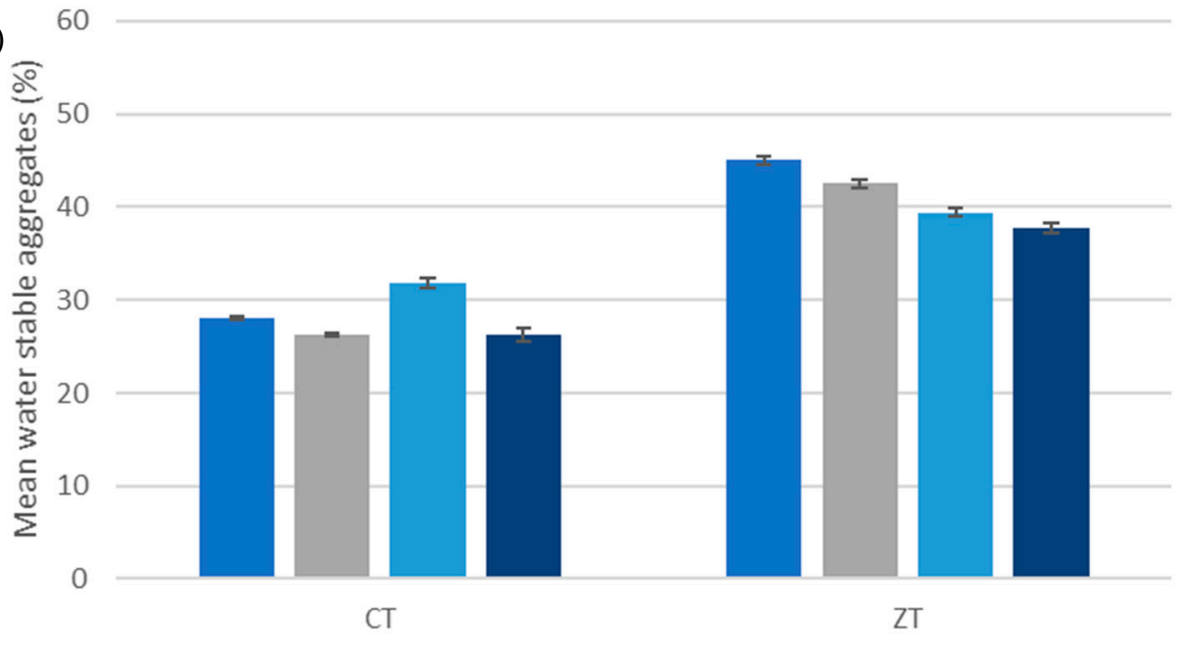

Tillage treatment

(b)

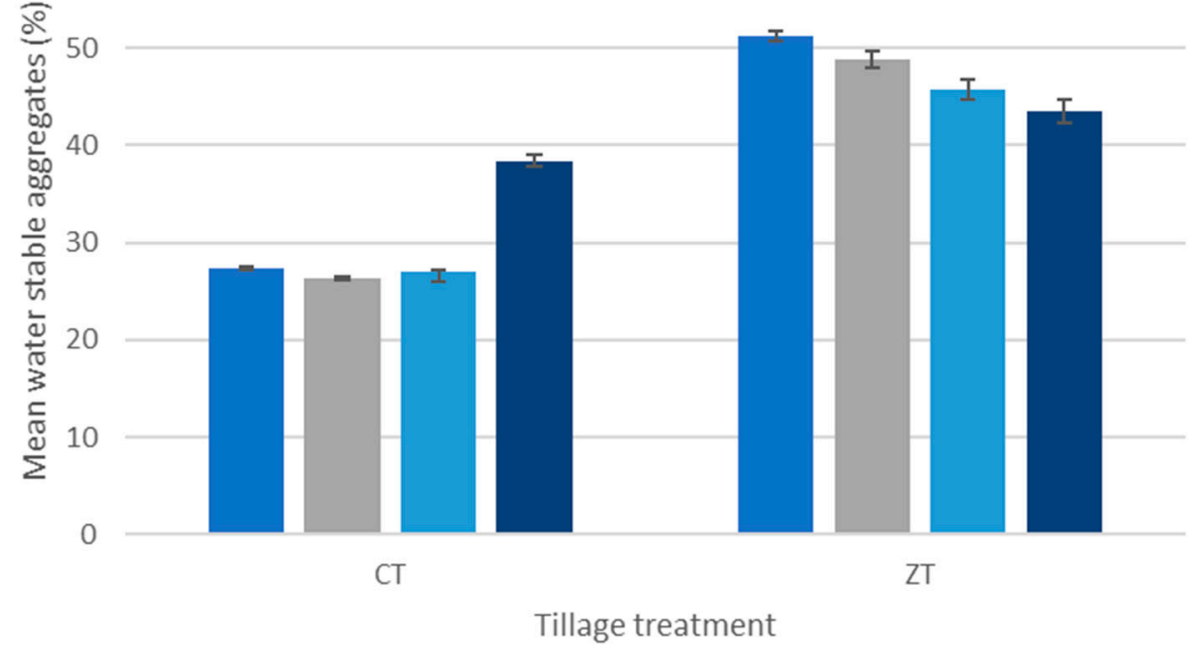

$\square 10 \mathrm{~cm} \quad 20 \mathrm{~cm} \quad \mathbf{\square} 30 \mathrm{~cm} \quad 40 \mathrm{~cm}$

Figure 5. Mean percentage water stable aggregates between tillage treatment (conventional tillage (CT) and zero tillage (ZT)) in (a) February and (b) May 2019. Sampled soils to a maximum depth of $40 \mathrm{~cm}$ at $10 \mathrm{~cm}$ increments. Zone of tillage in CT was noted to be to a sampling depth of $20 \mathrm{~cm}$ soil inversion. Error bars constructed from SEM.

The mean percentage SOM and proportion attributed to GRSP is displayed in Figure 6. Within ZT sampled soils, organic matter decreased significantly ( $p<0.00001$, df: 104, t.stat: -6.84 , paired equal variance $T$ test) between post cultivation and pre harvest. However, the contribution of glomalin to overall percentage organic matter increased, corresponding to a simultaneous increase in crop root development. CT soils (Figure 6) remained lower in overall percentage organic matter. Between post cultivation and pre harvest sampling, glomalin's contribution to overall organic matter percentage reduced, as did the remaining organic matter ( $p=0.01$, df: 395 , t.stat: 2.51 , paired equal variance $T$ test). Between tillage treatments, of each sampling period (Figure 6), overall organic matter percentage and glomalin's contribution were significantly different ( $p=0.01$, df: 395 , t.stat: 2.51 , paired unequal variance $T$ test) between tillage treatments for both sampling periods and are indicative of the impact of CT management practices. 


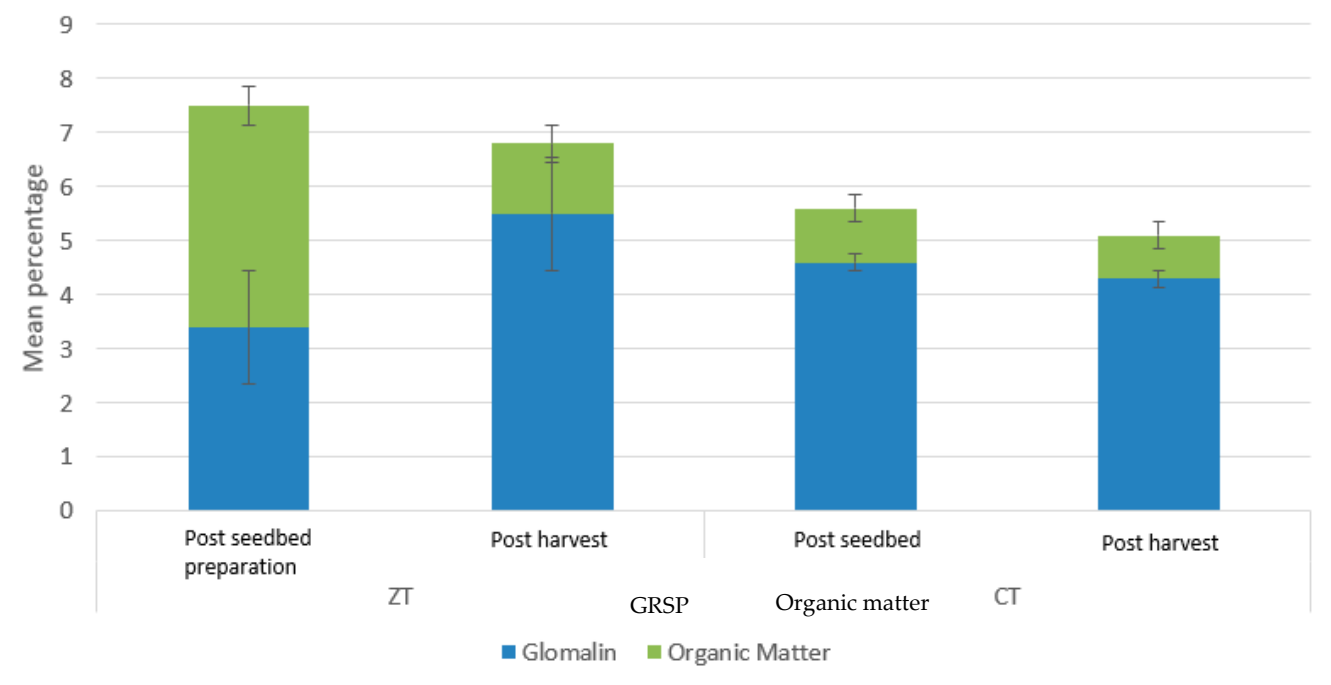

Figure 6. Breakdown of total soil organic matter from mean $(n=1408)$ organic matter and glomalin related soil protein (GRSP) percentage in sandy loam texture soils only of conventional tillage (CT) and zero tillage (ZT). Error bars constructed from SEM.

\section{Discussion}

The maintenance of a positive glomalin-WSA relationship, indicative of an intact AM fungal hyphae network [26] that both produces glomalin and physically binds soil particles, is critical to soil function. The present study has identified that the application of CT land management practices has a negative impact on this GRSP-WSA relationship. Furthermore, SOM was significantly higher in ZT soils sampled at depths of 10 and $40 \mathrm{~cm}$. The importance of considering both glomalin and WSA in combination is discussed.

The strong relationship between glomalin and WSA in ZT soils found here (Figure 1) indicates improvements to soil structure associated with conservation land management practices. This would not appear to be the case for $\mathrm{CT}$, where the erosion prevention properties of glomalin were lost due to the destruction of microaggregate adhesion. These findings correspond with those of [22,27], who also showed a reduction in glomalin and aggregate stability from the application of tillage. They did not, however, provide an understanding of the change to the glomalin-WSA relationship reported in the present study. Glomalin is produced by AM fungi as a structural support molecule along mycelia [3] to facilitate growth through pore spaces [5]. Soil inversion both reduces AM fungal abundance and therefore glomalin production but also physically destroys hyphal networks, which decreases aggregate stability and increases the risk of soil erosion [22,28]. In contrast, the lack of soil inversion associated with ZT both conserves the AM fungal mycelia networks and maintains glomalin production [29]. Not only does this increase aggregate stability, but it also results in higher SOM attributed to the glomalin molecule. The positive relationship between WSA and glomalin is present in four different soil textures throughout the soil profile under ZT (Figure 2). It suggests that ZT is beneficial for AM fungi over a broad range of soil types and over large areas of agricultural land.

The relationship between GRSP and WSA has been assessed in two different winter wheat crops. The key variable between the two sites was the method of seedbed preparation, specifically the presence or absence of soil inversion to a depth of $20 \mathrm{~cm}$ in the CT and ZT treatments, respectively. The strongest positive relationship between glomalin and WSA was observed in the ZT treatment. The quantity of soil glomalin alone did not signify greater WSA; a further underlying mechanism requires consideration. Curaqueo et al. [30] found that an increase in active hyphae enhanced soil glomalin but was also correlated with enhanced WSA in ZT soils. The total AM fungal hyphal length was reduced in CT managed soils $\left(3.5 \mathrm{~m} \cdot \mathrm{g}^{-1}\right)$ compared to ZT soils $\left(5 \mathrm{~m} \cdot \mathrm{g}^{-1}\right)$. Additionally, the length of active hyphae in CT soils was less $\left(0.5 \mathrm{~m} \cdot \mathrm{g}^{-1}, 14.3 \%\right.$ of total hyphal length) in comparison to ZT managed soils ( $1.0 \mathrm{~m} \cdot \mathrm{g}^{-1}, 20 \%$ of total hyphal length). The present study supports 
the findings of [30], noting a higher positive Pearson's correlation (0.85 Figure 1a, and 0.87 Figure 1b) between glomalin and WSA in the undisturbed ZT soils. The Pearson's correlation coefficient in the CT treatment was lower, although it increased slightly, from 0.07 to 0.13 , for the period post cultivation to pre harvest. This suggests that the regeneration of AM fungi mycelial networks during a single cropping cycle in an annually cultivated crop are marginal. In contrast, the positive correlation between WSA and total glomalin is maintained in ZT soils throughout the year.

The present study shows an overall reduction in soil aggregation and the GRSP-WSA relationship in CT managed soils. According to [28] and Hajabbasi and Hemmat [31], mycelial networks are damaged or destroyed by soil inversion, resulting in a lag phase in the development of plant-fungal associations. Zheng et al. [28] highlight a reduction in soil aggregate stability of $34 \%$ due to CT, a conclusion supported by this study. Where there is soil inversion, the WSA-enhancing properties of fungal hyphae are prevented. The destruction of fungal hyphal networks is also reported to decrease glomalin production [20,31,32]. If the absence of AM fungi due to physical destruction by CT reduces soil glomalin, the increase in glomalin in the zone of tillage in the CT treatment during February (Figure 4a) was somewhat unexpected. It is proposed that this, based on the conclusions of [3], is due to the deposition of glomalin within soils upon the death of the AM fungi. The lower correlation between glomalin and WSA in CT but not ZT (Figure 1) would support this assertion. Importantly, it emphasizes the need to not consider the quantity of soil glomalin in isolation as a positive indicator. While the presence of glomalin is indicative of AM fungal growth, increased glomalin alone does not necessarily indicate enhanced soil aggregation. Measured GRSP does not differentiate between a living hyphal network actively producing glomalin and a network that has been recently destroyed by physical soil disturbance. The emphasis here is on the recent nature of the timeframe, as glomalin production will cease and declines will be observed with increased time lapsed. The decline within three months between February and May also illustrates the detrimental impact of physical disturbance on the glomalin molecule itself, with a decrease in the quantity noted in a molecule that can, according to Wright et al. [5], persist for up to 40 years in undisturbed soils. This is despite crop root growth and the potential for the formation of a root-AM fungi association being at its most prolific during this period. Root symbiosis evidently declines in this part of the soil profile where physical disturbance has occurred even though the available plant root material is at its optimum. The ramifications continue for the duration of the entire cropping cycle. At the end of August, both the CT and ZT crops have been harvested, decreasing the available living plant root material with which the AM fungi may form symbiosis. While the quantity of glomalin is relatively similar between CT and ZT at this stage in the cropping cycle, the associated WSA for each tillage treatment are not. A potential shortcoming of seedbed preparation by ZT and the impact on AM fungi is the application of glyphosate as an alternative method of weed control [26]. The reduction in glomalin initially recorded in the top $20 \mathrm{~cm}$ of the soil profile post glyphosate application in September may be due to inhibition of key metabolic pathways in AM fungi [26,32]. Despite the decrease in AM fungi growth, the impact on WSA is not impacted detrimentally.

Several authors report how CT reduces SOM and the organic carbon component through the inversion and subsequent aeration of the soil, resulting in the oxidisation of carbon to $\mathrm{CO}_{2}[14,33]$. This would appear to be the case for CT soils analysed here, as both SOM (Figure 6) and WSA were higher in the soils of the ZT treatment compared to that of CT. Carbon is a constituent of both SOM and glomalin $[4,13]$. The lower quantities of glomalin and SOM in the CT soils have a number of implications. Firstly, the soil carbon store attributed to glomalin is reduced, decreasing its value in terms of climate change mitigation [34]. Further, the value of glomalin in preventing negative impacts, such as soil erosion through an increase in WSA, is diminished. The decline in glomalin overall suggests that its production, and therefore source, AM fungi [8,20,34-36]), has also been negatively impacted. AM fungi have an important role in crop systems by improving nutrient acquisition [37], aggregate stabilisation via mycelial networks [3] and carbon 
sequestration as glomalin coupled with the enhancement of WSA. Conventional tillage is detrimental to these three key soil functions.

Zero tillage increased GRSP overall relative to $\mathrm{CT}$ across the sampling year as a whole. Most importantly, the practice preserves the positive glomalin-WSA relationship through the maintenance of AM fungal hyphal networks, compared to CT management, thus the associated benefits provided to the crop grown. This is coupled with the potential for soil carbon storage attributed to the glomalin molecule. While reducing physical disturbance has a corresponding benefit, the environment created by ZT for AM fungi is not entirely optimal. Although the hyphal networks are maintained through limiting the physical disturbance of the soils, this may be compromised in part due to the elevated risk of unfavourable anaerobic soil conditions [38]. An increase in soil compaction coupled with a decline in soil aeration in ZT treatments has been noted by several studies [39-41] compared to soil conditions in CT [21]. Minimising soil compaction and the associated risk of anaerobic soil conditions in ZT systems is a key requirement in order to fully maximise the benefit to be derived from AM fungi.

Wang et al. [42] and Berruit et al. [39] both conclude that GRSPs were a proportionally greater contributor to soil carbon in deeper parts of the soil profile relative to the total percentage contribution to SOM. Bradley et al. [15] note the contribution of SOM to be greatest in the upper soil profile. In order to maximise soil carbon sequestration, the higher SOM reported in the upper soil profile of ZT systems requires integration with an increase in soil carbon in the lower soil profile provided by glomalin. Critically, it may offer a solution to the observations of Powlson et al. [43] that ZT does not increase soil carbon due to an increase in organic matter content overall but merely redistributes it within the soil profile; i.e., it increases in the upper profile while declining in the lower profile. This is hypothesised to be in part due to the lack of incorporation of crop residues into the lower soil profile in the absence of tillage [44]. Enhancing the abundance of AM fungi and the associated production of glomalin in the lower soil profile in ZT systems would potentially counter this issue; i.e., carbon within SOM will increase in the upper soil profile while simultaneously the carbon derived from glomalin is enhanced in the lower. The role of AM fungi in augmenting soil carbon cannot therefore be underestimated. Improved soil aeration in lower parts of the soil profile and the avoidance of soil compaction, a potential risk in ZT systems, are key, particularly in the small particulate clay soils. The enhancement of SOM is cited by Reicosky [45] as an answer but, as noted by Krauss et al. [44], may be difficult in ZT systems due to not being able to incorporate crop residues. The manipulation of crop rotations to include root crops with the capacity to penetrate compacted soils [46], coupled with low wheel pressure controlled-traffic farming [47,48], may offer potential solutions. Carbon sequestration and the associated benefits for climate change mitigation will potentially be enhanced, both through an increase in the organic matter content [49] and also from greater quantities of the carbon-containing glomalin molecule. The relationship between root crops and AM fungi and the impact on soil glomalin due to the inclusion of such crops within an arable rotation require further investigation.

\section{Conclusions}

This study has tested and upheld the hypothesis that two land management practices, $\mathrm{CT}$ and ZT, (1) influence AM fungi and (2) indirectly affect water stable macroaggregate formation, soil glomalin and SOM. Zero tillage maintains a positive glomalin-WSA relationship throughout the entire cropping year. This has positive implications towards enhanced SOM the storage of carbon within the glomalin molecule and preventing soil erosion. Conventional tillage may increase in soil glomalin at specific times of the cropping year, but this is not sustained, and crucially, the positive glomalin-WSA relationship indicative of intact fungal hyphal networks is not preserved. 
Author Contributions: Conceptualization, T.I.W.; methodology, T.I.W., I.D., K.G.D., V.E.-B. and D.J.W.; formal analysis, T.I.W. and V.E.-B.; investigation, T.I.W.; Writing-original draft preparation, T.I.W.; writing-review and editing, D.J.W., K.G.D., I.D. and V.E.-B.; supervision, D.J.W., K.G.D., I.D. and V.E.-B.; project administration, D.J.W., I.D. and K.G.D.; funding acquisition, D.J.W. All authors have read and agreed to the published version of the manuscript.

Funding: This research forms part of a Ph.D. studentship funded by the SALISBURY CHARITABLE TRUST.

Institutional Review Board Statement: Not applicable.

Informed Consent Statement: Not applicable.

Data Availability Statement: The data presented in this study are available on request from the corresponding author. The data are not publicly available due to confidentially aggrements.

Acknowledgments: The authors are grateful to the following: the two Hertfordshire farmers for permission to collect soil samples from their fields and the provision of crop management data.

Conflicts of Interest: The authors declare no conflict of interest. The funders had no role in the design of the study; in the collection, analyses, or interpretation of data; in the writing of the manuscript, or in the decision to publish the results.

\section{References}

1. Kottke, I.; Nebel, M. The evolution of mycorrhiza-like associations in liverworts: An update. New Phytol. 2005, 167, 330-334. [CrossRef] [PubMed]

2. Begum, N.; Qin, C.; Ahanger, M.A.; Raza, S.; Khan, M.I.; Ashraf, M.; Ahmed, N.; Zhang, L. Role of Arbuscu-lar Mycorrhizal Fungi in Plant Growth Regulation: Implications in Abiotic Stress Tolerance. Front. Plant Sci. 2019, 10, 1068. [CrossRef]

3. Driver, J.D.; Holben, W.E.; Rillig, M.C. Characterization of glomalin as a hyphal wall component of arbuscular mycorrhizal fungi. Soil Biol. Biochem. 2005, 37, 101-106. [CrossRef]

4. Lovelock, C.E.; Wright, S.F.; Clark, D.A.; Ruess, R.W. Soil stocks of glomalin produced by arbuscular mycorrhizal fungi across a tropical rain forest landscape. J. Ecol. 2004, 92, 278-287. [CrossRef]

5. Wright, S.F.; Frankee-Snyder, M.; Morton, J.B. Time-course study and partial characterization of a protein on hyphae of arbuscular mycorrhizal fungi during active colonization of roots. Plant Soil 1996, 181, 193-203. [CrossRef]

6. Rillig, M.; Wright, S.; Eviner, V. The role of arbuscular mycorrhizal fungi and glomalin in soil aggregation: Comparing effects of five plant species. Plant Soil 2002, 2, 325-333. [CrossRef]

7. Wilkes, T.I.; Warner, D.J.; Edmonds-Brown, V.; Davies, K.G.; Denholm, I. A comparison of methodologies for the staining and quantification of intracellular components of arbuscular mycorrhizal fungi in the root cortex of two varieties of winter wheat. Access Microbiol. 2020, 2, e000083. [CrossRef]

8. Wang, W.; Shi, J.; Xie, Q.; Jiang, Y.; Yu, N.; Wang, E. Nutrient Exchange and Regulation in Arbuscular Mycorrhizal Symbiosis. Mol. Plant 2017, 10, 1147-1158. [CrossRef]

9. Mathew, R.P.; Feng, Y.; Githinji, L.J.M.; Ankumah, R.O.; Balkcom, K.S. Impact of No-Tillage and Conventional Tillage Systems on Soil Microbial Communities. Appl. Environ. Soil Sci. 2012, 2012, 548620. [CrossRef]

10. Schwab, E.B.; Reeves, D.W.; Burnmester, C.H.; Raper, R.L. Conservation tillage systems for cotton in the Tennes-see Valley. Soil Sci. Soc. Am. J. 2002, 66, 569-577. [CrossRef]

11. Townsend, T.J.; Ramsden, S.J.; Wilson, P. How do we cultivate in England? Tillage practices in crop production systems. Soil Use Manag. 2015, 32, 106-117. [CrossRef] [PubMed]

12. Ostle, N.J.; Levy, P.; Evans, C.; Smith, P. UK land use and soil carbon sequestration. Land Use Policy 2009, 26, S274-S283. [CrossRef]

13. Smith, P. Soil carbon sequestration and biochar as negative emission technologies. Glob. Chang. Biol. 2016, 22, 1315-1324. [CrossRef] [PubMed]

14. Zhao, J.; Chen, S.; Hu, R.; Li, Y. Aggregate stability and size distribution of red soils under different land uses integrally regulated by soil organic matter, and iron and aluminum oxides. Soil Tillage Res. 2017, 167, 73-79. [CrossRef]

15. Bradley, R.; Milne, R.; Bell, J.; Lilly, A.; Jordan, C.; Higgins, A. A soil carbon and land use database for the United Kingdom. Soil Use Manag. 2005, 21, 363-369. [CrossRef]

16. Wang, Y.; Li, C.; Tu, C.; Hoyt, G.D.; DeForest, J.L.; Hu, S. Long-term no-tillage and organic input management en-hanced the diversity and stability of soil microbial community. Sci. Total Environ. 2017, 609, 341-347. [CrossRef]

17. Venter, Z.S.; Jacobs, K.; Hawkins, H.-J. The impact of crop rotation on soil microbial diversity: A meta-analysis. Pedobiologia 2016, 59, 215-223. [CrossRef]

18. Lupwayi, N.Z.; Arshad, M.A.; Rice, W.A.; Clayton, G.W. Bacterial diversity in water-stable aggregates of soils under conventional and zero tillage management. Appl. Soil Ecol. 2001, 16, 251-261. [CrossRef]

19. Lupwayi, N.Z.; Rice, W.A.; Clayton, G.W. Soil microbial diversity and community structure under wheat as influenced by tillage and crop rotation. Soil Biol. Biochem. 1998, 30, 1733-1741. [CrossRef] 
20. Wright, S.F.; Upadhyaya, A. A survey of soils for aggregate stability and glomalin, a glycoprotein produced by hyphae of arbuscular mycorrhizal fungi. Plant Soil 1996, 198, 97-107. [CrossRef]

21. Busari, M.; Kukal, A.; Kaur, A.; Bhatt, R.; Dulazi, A. Conservation tillage impacts on soil, crop and the environment. Int. Soil Water Conserv. Res. 2015, 3, 119-129. [CrossRef]

22. Lombardo, L.; Palese, A.M.; Grasso, F.; Duffy, D.H.; Bati, C.B.; Xiloyannis, C. Mechanical Tillage Diversely Affects Glomalin Content, Water Stable Aggregates and AM Fungal Community in the Soil Profiles of Two Differently Managed Olive Orchards. Biomolecules 2019, 9, 639. [CrossRef] [PubMed]

23. Brown, K.; Wherrett, A. Measuring Soil Texture in the Laboratory. 2015. Available online: http://soilquality.org.au/factsheets/ soil-texture-measuring-in-the-lab (accessed on 5 January 2020).

24. Myrbo, A.; Plank, C.; Coleman, J.; Shane, L.; Graber, D. Loss on ignition as a method for estimating organic and carbonate content. J. Paleolimnol. 2001, 25, 101-110.

25. Lancashire, P.D.; Bleiholder, H.; Langeluddecke, P.; Stauss, R.; van den Boom, T.; Weber, E.; Witzen-Berger, A. A uniform decimal code for growth stages of crops and weeds. Ann. Appl. Biol. 1991, 119, 561-601. [CrossRef]

26. Wilkes, T.I.; Warner, D.J.; Davies, K.G.; Edmonds-Brown, V.R. Tillage, glyphosate and beneficial Arbuscular Mycorrhizal fungi: Optimizing crop management for plant-fungal symbiosis. Agriculture 2020, 10, 520. [CrossRef]

27. Vaidya, G.S.; Rillig, M.; Wallander, H. The role of glomalin in soil erosion. Sci. World 2011, 9, 82-85. [CrossRef]

28. Zheng, H.; Liu, W.; Zheng, J.; Luo, Y.; Li, R.; Wang, H.; Qi, H. Effect of long-term tillage on soil aggregates and aggregate-associated carbon in black soil of Northeast China. PLoS ONE 2018, 13, e0199523. [CrossRef]

29. Brito, I.; Goss, M.J.; Carvalho, M.; Chatagnier, O.; Tuinen, D. Impact of tillage system on arbuscular mycorrhiza fungal communities in the soil under Mediterranean conditions. Soil Tillage 2012, 121, 63-67. [CrossRef]

30. Curaqueo, G.; Acevedo, E.; Cornejo, P.; Seguel, A.; Rubio, R.; Borie, F. Tillage effects on soil organic matter, mycorrhizal hyphae and aggregates in a Mediterranean agroecosystem. Rev. Cienc. Suelo Nutr. Veg. 2010, 10, 12-21. [CrossRef]

31. Hajabbasi, M.; Hemmat, A. Tillage impacts on aggregate stability and crop productivity in a clay-loam soil in central Iran. Soil Tillage Res. 2000, 56, 205-212. [CrossRef]

32. Lewis, K.; Tzilivakis, J.; Warner, D.J.; Green, A. An international database for pesticide risk assessments and management. Hum. Ecol. Risk Assess. Int. J. 2016, 22, 1050-1064. [CrossRef]

33. Haddaway, N.R.; Hedlund, K.; Jackson, L.E.; Kätterer, T.; Lugato, E.; Thomsen, I.K.; Jørgensen, H.B.; Isberg, P.-E. How does tillage intensity affect soil organic carbon? A systematic review protocol. Environ. Évid. 2016, 5, 1. [CrossRef]

34. Walley, F.; Gilliespie, A.; Adetona, A.; Germinda, J.; Farrell, R. Manipulation of rhizosphere organisms to en-hance glomalin production and C sequestration: Pitfalls and promises. Can. J. Plant Sci. 2013, 94, 1025-1032. [CrossRef]

35. Adeleke, A. Effect of Arbuscular Mycorrhizal Fungi and Plant Growth-Promoting Rhizobacteria on Glomalin Production. Master's Thesis, University of Saskatchewan, Saskatoon, SK, Canada, 2010.

36. Bendini, S.; Pellegrino, E.; Avio, L.; Pellegrino, S.; Bazzoffi, P.; Argese, E.; Giovannetti, M. Changes in soil aggrega-tion and glomalin-related soil protein content as affected by the arbuscular mycorrhizal fungal species Glomus mosseae and Glomus intraradices. Soil Biol. Biochem. 2009, 41, 1491-1496. [CrossRef]

37. Ingraffia, R.; Amato, G.; Frenda, A.S.; Giambalvo, D. Impacts of arbuscular mycorrhizal fungi on nutrient uptake, N2 fixation, N transfer, and growth in a wheat/faba bean intercropping system. PLoS ONE 2019, 14, e0213672. [CrossRef]

38. Berruti, A.; Lumini, E.; Balestrini, R.M.; Bianciotto, V. Arbuscular Mycorrhizal Fungi as Natural Biofertilizers: Let's Benefit from Past Successes. Front. Microbiol. 2016, 6, 1559. [CrossRef]

39. Calonego, J.C.; Raphael, J.P.; Rigon, J.P.G.; Neto, L.D.O.; Rosolem, C.A. Soil compaction management and soybean yields with cover crops under no-till and occasional chiseling. Eur. J. Agron. 2017, 85, 31-37. [CrossRef]

40. Nunes, M.R.; DeNardin, J.E.; Pauletto, E.A.; Faganello, A.; Pinto, L.F.S. Mitigation of clayey soil compaction managed under no-tillage. Soil Tillage Res. 2015, 148, 119-126. [CrossRef]

41. Teodor, R.; Moraru, P.; Ranta, O.; Drocas, I.; Bogdan, I.; Pop, A.; Sopterean, M. No tillage and minimum tillage-their impact on soil compaction, water dynamics, soil temperature and production on wheat, maize and soybean crop. Bull. Univ. Agric. Sci. Vet. Med. Cluj-Napoca. Agric. 2011, 68, 318-323.

42. Wang, W.; Zhong, Z.; Wang, Q.; Wang, H.; Fu, Y.; He, X. Glomalin contributed more to carbon, nutrients in deeper soils, and differently associated with climates and soil properties in vertical profiles. Sci. Rep. 2017, 7, 1-13. [CrossRef]

43. Powlson, D.S.; Stirling, C.M.; Jat, M.L.; Gerard, B.G.; Palm, C.A.; Sanchez, P.A.; Cassman, K.G. Limited potential of no-till agriculture for climate change mitigation. Nat. Clim. Chang. 2014, 4, 678-683. [CrossRef]

44. Krauss, M.; Ruser, R.; Müller, T.; Hansen, S.; Mäder, P.; Gattinger, A. Impact of reduced tillage on greenhouse gas emissions and soil carbon stocks in an organic grass-clover ley-winter wheat cropping sequence. Agric. Ecosyst. Environ. 2017, 239, 324-333. [CrossRef] [PubMed]

45. Reicosky, D.C. Conservation Agriculture: Global Environmental Benefits of Soil Carbon Management. In Conservation Agriculture; Springer: Dordrecht, The Netherlands, 2003; pp. 3-12.

46. Jabro, J.; Allen, B. Evaluation Effects of Deep Rooted Crops on Soil Compaction in a No-tillage System. EGU Gen. Assem. Conf. Abstr. 2018, 20, 1401.

47. Antille, D.; Peets, S.; Galambošová, J.; Botta, G.F.; Rataj, V.; Macak, M.; Chamen, T.; White, D.; Misiewicz, P.; Har-greaves, P.; et al. Review: Soil compaction and controlled traffic farming in arable and grass cropping systems. Agron. Res. 2019, 17, 653-682. 
48. Millington, W.A.J. The Effect of Low Ground Pressure and Controlled Traffic Farming Systems on Soil Properties and Crop Development for Three Tillage Systems. Ph.D. Thesis, Harper Adams University, Newport, UK, 2019.

49. Smith, P.; Soussana, J.F.; Angers, D.; Schipper, L.; Chenu, C.; Rasse, D.P.; Arias-Navarro, C. How to measure, re-port and verify soil carbon change to realize the potential of soil carbon sequestration for atmospheric greenhouse gas removal. Global Chang. Biol. 2020, 26, 219-241. [CrossRef] [PubMed] 